FULL LENGTH RESEARCH ARTICLE

\title{
IMPACT ASSESSMENT OF DUMPSITE LEACHATE ON THE QUALITIES OF SURFACE WATER AND SEDIMENT OF RIVER EKU, ONA-ARA LOCAL GOVERNMENT, OYO STATE, NIGERIA.
}

\author{
${ }^{*} \mathrm{NUBI}$, O. A. ${ }^{1}$ OSIBANJO, O. ${ }^{2}$ NUBI, A. T. ${ }^{3}$ \\ ${ }^{1}$ Nigerian Institute for Oceanography and Marine Research, Lagos, Nigeria. \\ ${ }^{2}$ Chemistry Department, University of Ibadan, Ibadan, Nigeria. \\ ${ }^{3}$ Environmental Laboratories Limited, P.O. Box 15104, Lagos, Nigeria. \\ *(Corresponding author) \\ oanubi@yahoo.com
}

\begin{abstract}
River Eku, a water body in Ona-Ara Local Government of Oyo State was studied to assess the impact of dumpsite leachate on the qualities of surface water and sediment of the river. The mean values for dissolved oxygen (DO) $(2.3 \pm 1.1 \mathrm{mg} / \mathrm{L})$, chemical oxygen demand (COD) $(822 \pm 658 \mathrm{mg} / \mathrm{L}), \mathrm{PO}_{4}{ }^{3-}(0.35 \pm 0.20 \mathrm{mg} / \mathrm{L}), \mathrm{SO}_{4}{ }^{2-}(16.45 \pm 2.95 \mathrm{mg} / \mathrm{L})$ were reported for the upstream region, while the downstream mean values for the same parameters gave $3.73 \pm 0.56 \mathrm{mg} / \mathrm{L}, 911.75 \pm 813.36 \mathrm{mg} / \mathrm{L}, 0.68 \pm 0.42 \mathrm{mg} / \mathrm{L}$, and $26.18 \pm 4.46 \mathrm{mg} / \mathrm{L}$ respectively. The dumpsite leachate was also analysed for the same parameters as for the water samples. The mean levels of some pollution parameters gave evidence of pollution in River Eku. The results obtained confirmed that the dumpsite leachate was the source of pollutants in the river.
\end{abstract}

Keywords: dumpsite, leachate, pollution, impact, anthropogenic, discharge

\section{INTRODUCTION}

Waste generation by man started since the beginning of civilization as a consequence of human activities, involving the production of goods and services, and the consumption of natural resources (Agenda 21, 1992). Population explosion, haphazardous rapid urbanization, industrial and technological expansion, energy utilization and wastes generation from domestic and industrial sources have rendered many water resources unwholesome and hazardous to man and other living resources. Water pollution is now a significant global problem.

Natural water is inflicted with a wide variety of inorganic, organic, and biological pollutants, a significant fraction of which come from improper waste disposal. In Nigeria, a variety of wastes originating from domestic and industrial sources find their way into streams and rivers due to weak enforcement of existing legislation and lack of basic infrastructure, such as sewers and hygienic disposal facilities (Sridhar \& Ademoroti, 1984).

The lack of data on waste generation and its effects on health and environment continue to be a major problem, thus hampering proper regulation. Very little is known about the health effects of wastes so that efforts to set exposure levels, to protect humans often prove ineffective. Sound management of wastes is a goal not yet achieved in many countries, even in the developed ones. Many of the recommended ways of waste disposal have been proven to be ineffective and some even pose further hazards. The aim of this study is to assess the impact of dumpsite leachate on the qualities of surface water and sediment of the River Eku, a water body in Ona-Ara Local Government of Oyo State.

Materials and methods.Study area: River Eku originates from Aba Epo in Ona Ara local government of Oyo State. The river flows through the thick forests of Idi Ose, Aperin, and finally into Omi. The river used to be clean until when the dumpsite located at Aba Epo polluted it from the influx of leachate runoff.

Sampling: The river under study was divided into three regions for sample collection. The upstream (US), point of discharge (POD), and downstream (DS). The collection design used was such that two (2), one (1), and three (3) samples of both water and sediment were collected at upstream, point of discharge, and downstream respectively. The selection of these points was influenced by accessibility to the river course. The condition of the river in wet season was also studied to know the impact in the worst case scenario. The distances of these points from the point of effluent discharge were measured. Composite sample of the leachate was also collected along the channel of discharge for analyses. The design was to enable the determination of the pollution potential of the leachate. Using the upstream portion as the background conditions, both the variation and impact of the leachate downstream were evaluated.

Sample analysis: Water samples for heavy metal determination were acidified in pre-cleaned plastic containers on the field. Each sample was collected in an acid-cleaned polypropylene bottle, which was rinsed three times with the sample water prior collection.

Samples for nutrients were filtered with Whatmann GF/C, $1.2 \mathrm{~mm}$ pore size filters immediately to remove any large particles, plankton and bacteria. Poisoning with mercuric chloride (1 drop saturated solution per $100 \mathrm{~mL}$ of sample) was also used to further aid in the preservation of the samples. Oxygen was fixed according to Winkler's method using Manganus sulphate and 
alkaline Potassium iodide. The collected samples were transported back to the laboratory the samples were kept in an ice cooler and upon arrival they were refrigerated at $4{ }^{\circ} \mathrm{C}$ and analysed within 1 wk.

Except for nitrate determination that was carried out using phenoldisulphonic acid spectophotometric method (Michael 1950), APHA-AWWA-WPCF method (1981) was used for all the parameters studied on water samples. The IITA (1979) method was used for determination of heavy metals in sediment samples.

\section{RESULTS}

The levels of the Physico-chemical parameters studied on River Eku are as presented in Table 1 and the variations in the Flow Rate, DO and COD along the course of the river presented in Fig. 1. The ranges for $D O$ and $C O D$ were found to be $(1.1 \mathrm{mg} / \mathrm{l}-4.3$ $\mathrm{mg} / \mathrm{l})$ and $87 \mathrm{mg} / \mathrm{l}-1480 \mathrm{mg} / \mathrm{l}$ ) respectively. The ranges reported for some physico-chemical parameters of this River showed that it belongs to the heavily polluted class IV or V (Osibanjo, 1994) (Table 4).
The COD value rose significantly at the point of discharge and fell drastically thereafter. Recovery was observed at DS1, DS2, and DS3 due to increased flow rates at these points (Fig. 1).

There were significant contributions from the leachate to the levels of COD, total hardness, total alkalinity, TS, and TDS but little contribution to the nitrate, phosphate and chloride levels by the leachate (Table 1). In all the parameter levels, the values at US2 were found to be higher than US1.This may be due to the back flow movement observed between US2 and POD during leachate intrusion.

The analytical results of concentration of heavy metals in the water samples from River Eku are shown in Table 2. The contributions of heavy metals to the surface water by the leachate appeared to be slight. However, higher values of Lead and Zinc were observed at US1. The source of this may be from vehicular emission along the course of the river in the upstream region. Table 3 presents the heavy metals contents and $\mathrm{pH}$ of sediment samples taken from the river.

\section{TABLE 1. PHYSICO-CHEMICAL PARAMETERS OF RIVER EKU WATER AND LEACHATE SAMPLES}

\begin{tabular}{|c|c|c|c|c|c|c|c|c|c|c|c|}
\hline Parameters & US1 & US2 & USMV & POD & DS1 & DS2 & DS3 & DSMV & Range & Leachate & $\begin{array}{l}\text { FEPA } \\
\text { (1991) }\end{array}$ \\
\hline Temp $\left({ }^{\circ} \mathrm{C}\right)$ & 30.9 & 30.3 & $30.6 \pm 0.3$ & 30.8 & 28.7 & 29 & 29.5 & $29.5 \pm 0.8$ & $28.7-30.9$ & 31.5 & $<40$ \\
\hline $\mathrm{pH}$ & 8.2 & 7.4 & $7.8 \pm 0.4$ & 6.3 & 7.8 & 7.5 & 7.5 & $7.28 \pm 0.58$ & $6.3-7.8$ & 4.7 & $6-9$ \\
\hline DO mg/L & 3.4 & 1.2 & $2.3 \pm 1.1$ & 1.1 & 3.9 & 3.9 & 4.3 & $3.73 \pm 0.56$ & $1.1-4.3$ & 1.8 & - \\
\hline COD mg/L & 164 & 1480 & $822 \pm 658$ & 1740 & 1710 & 110 & 87 & $911.75 \pm 813.36$ & $87-1480$ & 1870 & - \\
\hline Total Hard mg/L & 190 & 215 & $202.5 \pm 12.5$ & 223 & 219 & 211 & 193 & $211.5 \pm 11.52$ & $190-223$ & 228 & - \\
\hline Total Alkal mg/L & 215 & 228 & $221.5 \pm 6.5$ & 245 & 214 & 212 & 205 & $211.25 \pm 3.70$ & $205-245$ & 209 & - \\
\hline $\mathrm{Cl}^{-1} \mathrm{mg} / \mathrm{L}$ & 19 & 24 & $21.5 \pm 2.5$ & 33 & 33 & 32 & 21 & $29.75 \pm 5.07$ & 19-33 & 35 & 600 \\
\hline $\mathrm{SO}_{4}-2 \mathrm{mg} / \mathrm{L}$ & 13.5 & 19.4 & $16.45 \pm 2.95$ & 29.4 & 28.8 & 28 & 18.5 & $26.18 \pm 4.46$ & $13.5-29.4$ & 51 & 500 \\
\hline $\mathrm{PO}_{4}^{-3} \mathrm{mg} / \mathrm{L}$ & 0.15 & 0.54 & $0.35 \pm 0.20$ & 1.84 & 1.11 & 1.09 & 0.28 & $0.68 \pm 0.42$ & $0.15-1.84$ & 0.19 & 5 \\
\hline $\mathrm{NO}_{3}^{-} \mathrm{mg} / \mathrm{L}$ & 0.13 & 1.18 & $0.66 \pm 0.53$ & 1.24 & 1.38 & 1.39 & 1.90 & $1.48 \pm 0.25$ & $0.13-1.90$ & 1.21 & 20 \\
\hline $\mathrm{Ca} \mathrm{mg} / \mathrm{L}$ & 55.2 & 43 & $49.1 \pm 6.1$ & 59.8 & 40 & 39.4 & 31.7 & $42.73 \pm 10.39$ & $31.7-59.8$ & 64 & 200 \\
\hline Mg mg/L & 21.6 & 15.5 & $18.55 \pm 3.05$ & 23 & 12.7 & 12.3 & 11.4 & $14.85 \pm 4.73$ & $11.4-23$ & 29 & 200 \\
\hline T S mg/L & 2020 & 2850 & $2435 \pm 415$ & 2900 & 2450 & 2000 & 1900 & $2312.5 \pm 397.5$ & $1900-2900$ & 2950 & - \\
\hline TSS mg/L & 35 & 45 & $40 \pm 5$ & 45 & 35 & 30 & 30 & $35 \pm 6$ & $30-45$ & 50 & 30 \\
\hline TDS mg/L & 1985 & 2805 & $2395 \pm 410$ & 2855 & 2415 & 1970 & 1870 & $2277.5 \pm 391.5$ & $1870-2855$ & 2900 & 2000 \\
\hline Flow Rate $\mathrm{m} / \mathrm{s}$ & 0.37 & 0.16 & 0.27 & 0.15 & 0.19 & 0.28 & 0.36 & 0.28 & $0.15-0.37$ & & \\
\hline * Dist. $(\mathrm{m})$ & 150 & 60 & & 0 & 60 & 150 & 250 & & & & \\
\hline
\end{tabular}

USMV - Upstream mean value, DSMV - Downstream mean value, $\quad$ * Distance from point of discharge

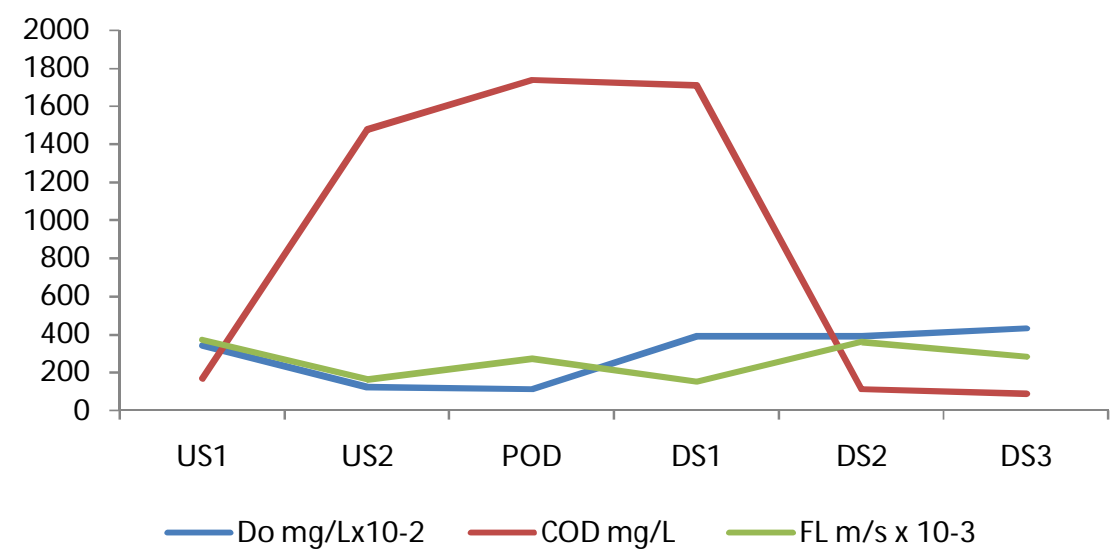

FIG. 1. COD-DO-FLOW RATE VARIATIONS ALONG THE SAMPLING POINTS 
TABLE 2. HEAVY METAL CONTENTS OF RIVER EKU SURFACE WATER

\begin{tabular}{|c|c|c|c|c|c|c|}
\hline \multirow[t]{2}{*}{ Sampling Points } & \multicolumn{6}{|c|}{ Heavy Metals $(\mu \mathrm{g} / \mathrm{ml})$} \\
\hline & $\mathrm{Ni}$ & $\mathrm{Cr}$ & $\mathrm{Zn}$ & $\mathrm{Pb}$ & $\mathrm{Cu}$ & $\mathrm{Cd}$ \\
\hline US1 & $<0.001$ & 0.005 & 0.32 & 0.42 & 0.004 & 0.011 \\
\hline US2 & ND & $N D$ & 0.26 & 0.014 & 0.018 & ND \\
\hline USMV & - & 0.005 & $0.29 \pm 0.03$ & $0.017 \pm 0.003$ & $0.011 \pm 0.007$ & 0.001 \\
\hline POD & 0.003 & 0.009 & 0.33 & 0.024 & 0.014 & 0.019 \\
\hline DS1 & 0.003 & 0.002 & 0.18 & 0.011 & 0.006 & 0.008 \\
\hline DS2 & ND & 0.004 & 0.32 & 0.015 & 0.119 & ND \\
\hline DS3 & ND & 0.002 & 0.25 & 0.01 & 0.111 & ND \\
\hline DSMV & 0.003 & $0.004 \pm 0.003$ & $0.27 \pm 0.06$ & $0.015 \pm 0.006$ & $0.063 \pm 0.053$ & $0.014 \pm 0.006$ \\
\hline Range & ND-0.003 & ND-0.009 & $0.18-0.33$ & $0.01-0.42$ & $0.004-0.119$ & ND-0.019 \\
\hline Leachate & 0.007 & 0.014 & 0.48 & 0.073 & 0.018 & 0.029 \\
\hline FEPA (1991) & $<1$ & $<1$ & $<1$ & $<1$ & $<1$ & $<1$ \\
\hline
\end{tabular}

TABLE 3. HEAVY METAL LEVELS AND pH OF RIVER EKU SEDIMENTS

\begin{tabular}{l|ccccccc}
\hline $\begin{array}{l}\text { Sample } \\
\text { Points }\end{array}$ & \multicolumn{7}{c}{ Concentration of heavy metals $(\mu \mathrm{g} / \mathrm{g})$} \\
$\mathrm{Ni}$ & $\mathrm{Cr}$ & $\mathrm{Zn}$ & $\mathrm{Pb}$ & $\mathrm{Cu}$ & $\mathrm{Cd}$ & $\mathrm{pH}$ \\
\hline US1 & 4.84 & 3.47 & 77.13 & 19.14 & 11.62 & 1.32 & 7.5 \\
US2 & 2.63 & 1.09 & 56.05 & 8.53 & 13.65 & 0.43 & 7.9 \\
USMV & $3.74 \pm 1.11$ & $2.28 \pm 1.19$ & $66.59 \pm 10.54$ & $13.84 \pm 5.31$ & $12.64 \pm 1.02$ & $0.88 \pm 0.45$ & $7.7 \pm 0.2$ \\
POD & 12.89 & 23.50 & 106.20 & 38.30 & 16.24 & 1.93 & 7.4 \\
DS1 & 3.42 & 2.99 & 88.10 & 9.44 & 15.93 & 0.75 & 7.2 \\
DS2 & 2.47 & 2.19 & 64.24 & 5.80 & 12.27 & 0.64 & 7.6 \\
DS3 & 2.35 & 1.92 & 78.22 & 3.19 & 12.12 & 0.41 & 7.7 \\
DSMV & $5.28 \pm 4.41$ & $7.65 \pm 9.16$ & $84.19 \pm 15.28$ & $14.18 \pm 14.10$ & $14.14 \pm 1.95$ & $0.93 \pm 0.59$ & $7.48 \pm 0.19$ \\
Range & $2.35-12.89$ & $1.09-23.50$ & $56.05-106.20$ & $3.19-38.30$ & $11.62-16.24$ & $0.41-1.93$ & $7.2-7.9$ \\
\hline
\end{tabular}

TABLE 4. SOME PARAMETERS USED IN THE CLASSIFICATION OF SURFACE WATER QUALITY (Osibanjo, 1994)

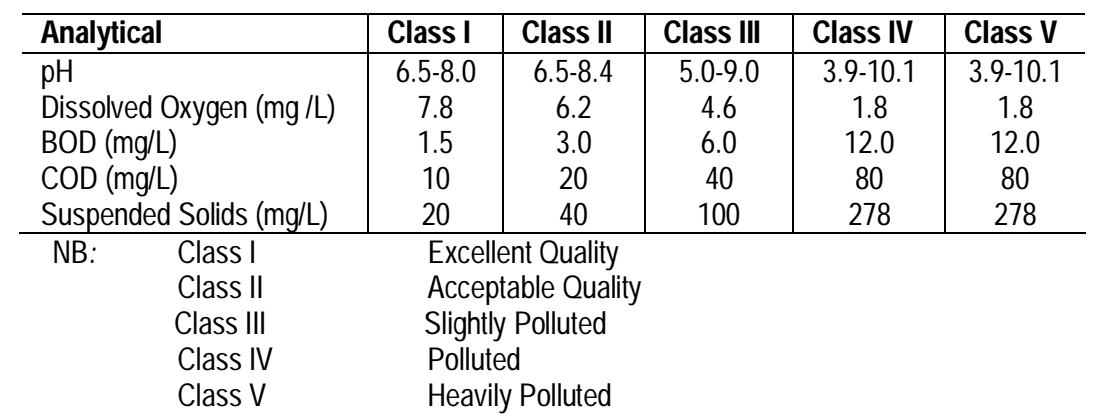

\section{DISCUSSION}

The ranges recorded for Lead and Zinc were found to be higher than the corresponding values quoted for both Ibadan surface water (Kakulu \& Osibanjo, 1991) and the international freshwater average. All the metal values were higher than the metal concentrations of some streams and lakes in Ibadan, as reported by Mombeshora et al., (1981). The Lead and Zinc values were at some points of the River course higher than the quoted maximum limits for WHO (2004) and USEPA (1994).

The general trend for heavy metals in sediment was Zinc $>$ Lead $>$ Chromium > Copper > Nickel > Cadmium. Using the metal concentration of Prater \& Anderson (1997), the range of zinc concentration placed the sediments from River Eku on "b" pollutional status i.e. moderately polluted.
The levels for the physico-chemical parameters and heavy metals of leachate from the Akanran dumpsite are included in Tables 1 and 3 respectively. Generally, the expectation that the leachate could be organically loaded was confirmed by the low DO and high COD values. The leachate was generally high in all the studied physicochemical parameters. A relatively low $\mathrm{pH}$ of 4.7 was recorded for the leachate sample. This confirmed the high level of sulphate in the leachate. The values for total solids and TDS were significantly high. The trend for heavy metals was zinc>lead>cadmium>copper>chromium>nickel. Except for Zinc, the observed level for heavy metals in the leachate showed that it was not rich in heavy metals. This supports the fact that road run-off and vehicular emissions may be major contributor to heavy metal levels in the River. 
The degree of pollution was ascribed to contribution from the leachate generated from the wastes at the dumpsite. The reduced water volume, observed at the time of sampling made the pollutants more concentrated and pollution level more intense. Based on the outcome of this study, steps need to be taken to review the efficiency of refuse dumpsites in Nigeria. It is obvious that advancement on the existing technology is highly imperative. To forestall leaching of pollutants into water bodies, location of dumpsites should be at an appreciable distance to our water bodies. In addition, municipal dumpsites should be replaced with proper engineered landfills.

\section{ACKNOWLEDGMENT}

The authors are grateful to the Chemistry department, University of Ibadan, Nigeria for providing the materials for sample collection and analyses.

\section{REFERENCES}

Agenda 21, (1992): Environmentally Sound Management of Solid Wastes and Sewage - Related Issues. Earth Summit, Rio de Janeiro, Chapter 21.

APHA-AWWA-WPCF (1981): Standard Methods for the examination of water and wastewater, edited by Anold, E.G. Joseph, J.C. \& David, J. 15th edition, R. R. Donelley and Sons Company, U.S.A. pp 547.

FEPA (1991): Guidelines and Standards for Environmental Pollution Control in Nigeria.
IITA (1979): Selected Methods for Soil and Plant analysis. Manual Series No. 1, International Institute for Tropical Agriculture, Ibadan Nigeria pp. 70.

Kakulu, S.E. and Osibanjo, O. (1992): Pollution Studies of Nigerian Rivers. Trace metal levels in surface waters of the Niger Delta. International Journal of Environmental Studies, 41, 287-292

Michael, J. T. (1950): Phenoldisulphonic Acid method of determining nitrate in water. Analytical Chemistry, 22(8), 20 - 22.

Mombeshora, C., Ajayi, S. O. \& Osibanjo, O. (1981): Pollution studies of Nigerian River I: Toxic heavy metals status of surface waters in Ibadan city. Environmental International, 5:49-53.

Osibanjo, O. (1994): Present water quality status in Nigeria. Federal Environmental Protection Agency, Lagos, Nigeria.

Prater, B. L. \& Anderson, M. A. (1977): Assessment of pollutional status of sediments according to metals concentration Journal of Water Pollution Canference. 2, 2099.

Sridhar, M. K. C. \& Ademoroti, C. M. A. (1984): Effluent discharge standards required in Nigeria. African Water and Sewage, 3:32-36.

USEPA (1994): Water Quality Standards Handbook: Second Edition EPA-823-B-94-005; August 1994

WHO (2004): Guidelines for drinking-water quality, Vol. 1, 3rd edition incorporating 1st and 2nd addenda. pp 515. 